\title{
Sağlık çalışanlarının maruz kaldıkları iş stresi ile iş doyumu ilişkisinin incelenmesi: bir meta- analiz çalışması
}

\begin{abstract}
Sait SÖYLER ${ }^{1}$
$\ddot{\mathbf{O} z}$

İşletmelerin rekabet üstünlüğü elde edebilmeleri adına sahip oldukları insan kaynağının verimliliğini maksimum seviyelere çıkarmaları gerekmektedir. İnsan kaynaklarının yüksek performans ile çalışabilmesi ise iş tatminleri ile doğrudan bağlantılıdır. Her ne kadar iş tatminini etkileyen çok sayıda unsur olsa da, maruz kalınan iş stresi bu unsurların en önemlilerinden biri olarak dikkat çekmektedir. Bu bağlamda bu çalışmanın amacı sağlık çalışanlarında iş stresi ve iş tatmini arasındaki ilişkinin etki büyüklüğünü açıklamaktır. Araştırmada yöntem olarak meta analiz kullanılmıştır. Veri niteliğindeki çalışmalara ulaşabilmek amacı ile PubMed ve ulusal tez merkezi veri tabanları kullanılmıştır. Ulusal ve uluslararası çalışmalar taranmış ve iş tatmini ile iş stresi ilişkisini inceleyen, dahil edilme kriterlerini sağlayan çalışmalar araştırmaya dahil edilmiştir. Yapılan meta analiz sonuçlarına göre, iş stresinin iş tatmini üzerindeki etki büyüklüğü $-0,275$ olarak tespit edilmiştir. Dolayısı ile araştırma sonucunda iş stresinin iş tatminini negatif yönde ve orta düzeyde etkilediği sonucuna ulaşılmıştır. Sağlık çalışanları, yapılan hataların bedellerinin çok ağır olduğu bir sektörde faaliyet göstermektedirler. Bu nedenle sağlık çalışanlarının maruz kaldıkları stresi azaltıcı önlemler alınmalı ve iş doyumları artırılmalıdır.
\end{abstract}

Anahtar Kelimeler: İş tatmini, iş stresi, sağlık, sağlık çalışanları, meta analiz
Yayın Bilgisi

Gönderi Tarihi:19.03.2018

Kabul Tarihi:13.05.2018

Online Yayın Tarihi:31.12.2018

DOI: $10.26453 /$ otjhs.407771

Sorumlu Yazar

Sait SÖYLER

\section{Examining the relationship between job stress and job satisfaction that health workers are exposed to: a meta-analysis study}

\section{Sait SÖYLER ${ }^{1}$}

\begin{abstract}
Businesses need to maximize the efficiency of their human resources in order to have competitive advantage. The ability of human resources to work with high performance is directly related with job satisfaction. The occupational stress is one of the most important factors although there are many affecting it. In this context, the purpose of this study is to determine the effect size of job stress on job satisfaction in healthcare sector. Method: Metaanalysis has been used in the study. The PubMed and national thesis center databases have been searched by the keywords to achieve papers. National and international papers have been overviewed. The studies examining the relationship between job satisfaction and job stress and having the inclusion criteria are included in the study. According to the results of the meta-analysis, the effect size of job stress on job satisfaction is found -0.275 . As a result of this study, it is observed that there is negative and moderate effect of occupational stress on job satisfaction. Healthcare sector cannot tolerate mistakes because it is strongly related with human life. For this reason, measures should be taken to reduce the stress that health workers are exposed to and their job satisfaction should be increased.
\end{abstract}

Article Info

Keywords: Job satisfaction, occupational stress, health, health workers, meta analysis

Corresponding Author

Received:19.03.2018

Accepted:13.05.2018

Online Published:31.12.2018

DOI: $10.26453 /$ otjhs.407771

Sait SÖYLER

${ }^{1}$ Altınbaş Üniversitesi Sağlık Hizmetleri Meslek Yüksekokulu, İstanbul 


\section{GíRiș}

Günümüzde rekabet ortamı, geçmişin herhangi bir döneminden çok daha yüksek seviyelere ulaşmıştır. Bunun başlıca sebepleri arasında, yirminci yüzyılın sonlarında zirveye çıkan küreselleşme, hızlanan ulaşım imkânları, internetin günlük yaşamda önemli bir yer kaplamaya başlaması ve uluslararası/çok uluslu şirketlerin pazar rekabeti gelmektedir. Yoğun rekabet ortamında işletmeler minimum maliyet ile maksimum seviyede çıktı elde etmeye odaklanmaktadır. Bunu başarabilmenin yolu da nitelikli ve yüksek performanslı insan kaynaklarından geçmektedir. İnsan kaynaklarının yüksek performansla çalışabilmesi de çok çeşitli faktörlere bağlıdır. $\mathrm{Bu}$ faktörlerin en önemlilerinden biri, çalışanların iş tatminlerinin yüksek olmasıdır. İş tatmini yüksek olan çalışanlar diğer çalışanlara göre daha yüksek verimlilik ile çalışabilmekte, işletmelerine rekabet avantaj sağlayabilmektedir. Çalışanların maruz kaldıkları iș stresi göz önünde bulundurulduğunda, iş streslerinin iş tatminlerini etkilediği ve dolayısıyla iş stresinin çalışan performansı üzerinde de etkisi olduğu net olarak görülebilecektir.

Sağlik sektörünün hataya tolerans gösterilemeyecek bir sektör olması ve hem beșeri hem de teknik bilginin aynı anda kullanılmasını gerektirmesi, bu alanda çalışan bireylerin iş stresini artırmakta, bu durum da iş tatminlerine ve dolayısı ile performanslarına

olumsuz olarak yansımaktadır. Bu bağlamda bu çalışmada, literatürde yer alan ve farklı örneklemler ile çalışılmış olan araştırmaların meta analiz yöntemi ile incelenmesi ve iş stresinin iş tatmini üzerindeki etki büyüklüğünün hesaplanması amaçlanmıştır.

\section{Stres kavramı}

Literatürde stres ile ilgili çok sayıda tanım yer almaktadır. $\mathrm{Bu}$ tanımlar üzerinde ise bir fikir birliğine varılamamakta, her araştırmacı kendi disiplini ile ilgili olarak stres kavramına farkl açılardan yaklaşmaktadır. Stres kavramı ile ilgili terminoloji yarım asırdan uzun bir süredir tıp, davranış bilimleri, sosyal bilimler gibi alanlarda çalışmalar yapan kişiler tarafından farklı şekillerde tanımlanmış, bu durum da literatürde ortak bir tanımın yer almasının önüne geçmiştir. Stres genellikle üç farklı açıdan ele alınmıș ve tanımlarda stresi bir yanıt, uyarıcı veya çevre ile ilişkiden kaynaklanan bir etkileşim olarak tanımlayan ifadeler yer almıştır. ${ }^{1}$ Fen ve doğa bilimleri ile davranış bilimlerinde de stres farklı şekillerde tanımlanmıştır. Fen ve doğa bilimlerine göre stres; vücut üzerinde deformasyon veya şekil değişikliklerine yol açan bir güç olarak tanımlanırken, davranış bilimlerine göre stres; gerginlik yaratan bir durum ile ilgili olarak yaşanan gerginlik, hasar ve gerilime karşı direnç sonuçları doğuran ekstrem durumlar olarak tanımlanmaktadır. ${ }^{2}$ Bir diğer tanıma göre ise stres, bireylerin çevreleri ile yaşadıkları uyumsuzluklar neticesinde, çevrelerinden gelen mevcut ve potansiyel 
tehditlere ilişkin gösterdikleri fiziksel ve psikolojik belirtilerdir. Strese maruz kalan kişilerde nabzın ve solunumun artması, yorgunluk, uyku bozuklukları gibi hem fiziksel hem de psikolojik belirtiler görülebilmektedir. Bireyler en fazla çalışma ortamlarında stresle karşılaşmaktadırlar. İş yaşamında stres nedenleri arasında aşırı ses, 1şık, 1s1, kişinin becerilerine uygun olmayan, çok hafif veya çok ağır oranlardaki sorumluluklar, aşırı veya çok az denetim gibi unsurlar gösterilebilir. Her bireyin yaşanan stres neticesinde göstereceği tepki farklıdır. Stres kimi bireylerde yükselen iş performansı ve verimlilik ile sonuçlanırken kimilerinde ise rahatsızlık, saldırganlık, işi aksatma gibi sonuçlara yol açabilmektedir. ${ }^{3}$

Stresin oluşumunda etkili olan çok sayıda faktör sekiz ana başlık altında; bireyin kendisi ile ilgili faktörler, iş çevresi ile ilgili faktörler, bireyin yaşamını sürdürdüğü genel çevresi ile ilgili faktörler, ülke ve dünya ekonomisinde yaşanan belirsizlikler ile ilgili faktörler, politik hayatın belirsizliği ile ilgili faktörler, çalışılan kente ilişkin faktörler, teknolojik değişim ile ilgili faktörler ve sosyal ve kültürel değişimlerden kaynaklanan faktörler olarak toplanabilir. ${ }^{4}$

Çalışanların iş çevreleri ile ilgili stres kaynakları geniş bir yelpazede ele alınabilmektedir. Çalışma koşulları ve işin yapısı bir stres kaynağı olabilmektedir. ${ }^{5}$ Çalışılan yerdeki kaza ve hastalık riskleri, hava kirliliği, mikroplu ve nemli ortamlar, çalışanların kendilerini tehlikede hissetmelerine ve dolayısı ile sürekli alarm halinde olmalarına neden olmaktadır. Diğer taraftan işyeri organizasyonu ile ilgili yaşanan problemler, iş bölümü ve iş akışının düzensiz olması bireylerin çalışma kalitesini ve verimini düşürmekte, bu durum hem çalışanlar hem de yöneticiler açısından stres oluşturabilmektedir. İş yerinde yapılması beklenen işler ile kişilerin yetenek ve kapasitelerinin uyumsuz olması diğer bir stres kaynağıdır. ${ }^{6}$ Günümüzde özellikle İstanbul gibi metropollerde yaşayan insanların stres kaynaklarından biri de iş yerine olan fiziksel uzaklıklarıdır. Bireylerin ulaşım ile ilgili kaygıları, işe gidiş ve dönüş saatlerinde yaşadıkları stres, hem kendilerini hem de çalışma arkadaşlarını etkileyebilen bir stres kaynağıdır. ${ }^{4}$ İş ile ilgili faktörlerden bir diğeri ise ücret yetersizliğidir. ${ }^{7}$ Hılılı teknik gelişmeler, bireylerin sürekli ayak uydurmak zorunda oldukları değişikliklerdir ve bu durum çalışanlarda stres yaratabilmektedir. ${ }^{8}$ Örgütsel yap1 içerisinde daha üst konumlara yükselme isteği hem güdüleyici hem de stres yaratıcı bir faktör olabilmektedir. Ayrıca yükselme beklentisinin karşılanmaması kişide hayal kırıklığı ve stresin görülmesine sebep olabilmektedir. ${ }^{9}$ Bireylerin kişilik yapılarına ve verimli çalışma yöntemlerine uygun olmayan işlerde ve koşullarda çalışması da önemli bir stres kaynağı olarak görülmektedir., ${ }^{410}$

\section{Stresin etkileri}

Stres hem bireyler üzerinde hem de örgütler üzerinde olumsuz etkilere sahiptir. Stresin 
bireysel bazda neden olduğu sorunlar hem fiziksel hem de psikolojik olabilmektedir. $\mathrm{Bu}$ problemler başlangıçta çeşitli düzeylerde stres belirtileri iken ilerleyen aşamalarda hayati tehlikeye sebebiyet verebilecek hastalıklara yol açabilmektedir. ${ }^{11}$ Stres öncelikle kalp ve damar hastalıkları ve sindirim, boşaltım ve solunum sistemleri ile ilgili problemlere sebep olabilmektedir. $\mathrm{Bu}$ kapsamda çarpıntı, damar sertleşmesi, yüksek tansiyon, astım, gastrit, ülser gibi hastalıklar görülebilmektedir. Aynı zamanda egzama, saç dökülmesi gibi cilt problemleri, cinsel iktidarsızlık gibi üreme problemleri ve kas ağrıları ile spazmlar gibi hareket sistemi hastalıkları da görülebilmektedir. ${ }^{11}$ Psikolojik olarak ise duygusal travmalar, depresyon, anksiyete, uyku bozuklukları, madde bağımlılıkları, tükenmişlik sendromu gibi sorunlar ile karş1laş1labilmektedir. ${ }^{4,11,12}$

Stresin örgüt üzerindeki olumsuz etkileri, iş görenin veriminin ve yaptığı işin kalitesinin düşmesi, işe yabancılaşma, devamsızlıkların artması, iş gören devir oranlarının yükselmesi olarak sıralanabilir. Öte yandan iş görenlerin yoğun stres altında çalışması iş kazalarının görülme sıklığını artırabileceği ve çeşitli hastalıklara sebep olabileceği için örgüt hem iş gücünden yoksun kalabilmekte hem de çeşitli masraflara katlanarak ekonomik olarak zarar görebilmektedir. ${ }^{13}$

Stres bireyler açısından makul düzeyde kaldığı sürece motive edici olabilmektedir. Ilımlı bir

düzeyde stres yaşamak monoton ve tekdüze bir çalışma yaşamını engelleyerek çalışan üzerinde pozitif etkiler yaratmaktadır. ${ }^{14}$ Ancak aşırı strese maruz kalan çalışanların iş yerindeki verimlilikleri düşmekte, kişiler arası ilişkileri bozulabilmekte, örgüt bu durumdan zarar görebilmektedir. ${ }^{7} \mathrm{Bu}$ nedenle stresin kontrol edilmesi ve stres ile başa çıkma yöntemlerinin geliştirilmesi önem kazanmaktadır.

\section{İş tatmini kavramı}

İş doyumu veya iş tatmini, çalışanın işten kaynaklanan maddi kazancı ile takım çalışması sonucunda ortaya koyduğu somut eserlerden sağladığı mutluluk olarak tanımlanabilir. ${ }^{15}$ İş tatmini, en geniş anlamda çalışanların iş ile ilgili hissettikleri olumlu duygular olarak ifade edilmektedir. ${ }^{16}$ İş tatmini çalışanların elde ettiği ekonomik kazançlar ile çalışılan ortamın güvenliği ile, yapılan iş ile yeteneklerin uyumu ile, elde edilen çıktılardan duyulan mutluluk ile, iş yerindeki insan ilişkileri ile, amirin veya amirlerin tutumu ve işletmenin içerisinde bulunduğu durum

ile ilişkilendirilebilmektedir. ${ }^{17}$

Bireylerin beklentileri ile gerçekleşen durumlar arasındaki uyum veya uyumsuzluk da iș tatminini doğrudan etkilemektedir. ${ }^{18}$

İş tatmini hem çalışanların bireysel olarak iyi oluşlarını hem de işletmelerin faaliyetlerini sağlıklı olarak yürütebilmesini etkilemesi nedeni ile üzerinde önemle durulması gereken bir konudur. İş tatmini birebir görüşmeler yolu 
ile ölçülebilse de genellikle ölçek kullanımı tercih edilmektedir. Ölçeklerde genellikle; ücretler ve ücret artışları ile ilgili tatmin, terfî olanakları ile ilgili tatmin, gözeticiler ile ilgili tatmin, yan ödemeler ile ilgili tatmin, ödüller ile ilgili tatmin, iş arkadaşları ile ilgili tatmin, yapılan iş ile ilgili tatmin ve örgütsel iletişim ile ilgili tatmin alt boyutları ve bunlara ilişkin sorular yer almaktadır. ${ }^{19}$

Çalışanların işlerinden tatmin olmaması nedeni ile sergileyebilecekleri bir takım davranışlar vardır. $\mathrm{Bu}$ davranışlar genel anlamda dört ana başlık altında incelenmektedir: "Çıkış, söz hakk1, sadakat ve ihmal". ${ }^{16}$

Çıkış: Çıkış davranışı çalışanı işletmeden ayrılmaya yöneltmektedir. Çalışanlar yeni bir iş arayışına girişirler.

Söz hakkl: Söz hakkı davranışı çalışanı amirleri ile iletişim kurmaya, sorunlara çözüm getirmeye ve yapıcı öneriler getirmeye yönlendirmektedir.

Sadakat: $\mathrm{Bu}$ davranış çalışanın örgüte bağlı kalarak, yöneticilere güvendiğini belli ederek ve gelen eleştirilere karşın işletmeyi savunarak problemlerin düzeleceği inancından ileri gelmektedir.

Ihmal: $\mathrm{Bu}$ davranışta ise çalışan probleme karşı pasif kalarak durumun daha da kötüleşmesine izin verme yolu ile tatminsizliğini ifade etmektedir.

Burada söz hakkı ve sadakat davranışları problemlerin çözülmesine ve koşulların yeniden yapılandırılmasına katkı sağlayabilecek şekilde yapıcı, çıkış ve ihmal davranışları ise üretkenliği azaltıcı, işe devamsızlığı ve iş gören devrini artırıcı şekilde yıkıcıdır. ${ }^{16}$

Günümüzün rekabet koşullarında çalışanlar bir işletmeyi diğerinden farklı kılacak, o işletmeye rekabet üstünlüğü kazandıracak ve ileriye götürecek olan belki de en önemli unsurdur. $\mathrm{Bu}$ nedenle iş tatmini yüksek çalışanlar, hem bireysel performanslarını hem de kurumsal performansı üst seviyelere çekebilecektir. ${ }^{20}$ İş tatmini ile ilgili yapılan çok sayıda araştırma vardır ve bu araștırmaların bazılarında iș tatmini bağımlı değişken iken bazılarında bağımsız değişkendir. Yani iş tatminini etkileyen çok sayıda değişken varken iş tatmininin etkilediği de bir o kadar değişken vardır. İş tatmini; bireysel ve kurumsal performans1, örgütsel vatandaşlık tutumlarını, müşteri tatminini, devamsızlık oranlarını ve iş gücü devir oranlarını direkt olarak etkileyen önemli bir faktördür. ${ }^{16}$ Aynı şekilde ücret, terfi imkanları, işin çalışan kişinin becerileri ile uyumlu olması gibi faktörler de iş tatminini doğrudan etkilemektedir. ${ }^{16} \mathrm{Bu}$ faktörlerin yanı sıra son zamanlarda iș stresinin iș tatmini üzerindeki etkisini inceleyen çok sayıda çalışma da literatürdeki yerini almıştır. Çalışmaların çoğunda iş stresinin iş tatminini olumsuz yönde etkilediği sonucuna varılmış, bazı araştırmalarda ise iş tatmini ile iş stresi arasında istatistiksel olarak anlamlı bir ilişkiye rastlanmamıştır. 
$\mathrm{Bu}$ çalışmanın amacı sağlık çalışanlarında iş stresi ve iş tatmini arasındaki ilişkiyi inceleyen bilimsel çalışmaların meta analiz yöntemi ile analiz edilerek iş stresinin iş tatmini üzerindeki etki büyüklügünü açıklamaktır.

\section{MATERYAL VE METOT}

Araştırmada yöntem olarak meta analiz kullanılmıştır. Meta analiz, belirli bir konu ile ilgili olarak, farklı coğrafi alanlarda farklı örneklemler ile yapılan çalışmaların örneklemlerinin ve sonuçlarının bir araya getirilmesi ve kantitatif verilerin yorumlanması ile yapılan bir analizdir. Bu kapsamda sağlık çalışanlarından oluşan örneklemlerde yapılan tez ve makalelerden meta analiz çalışması açısından uygun olanlar seçilmiştir. Bu kriterler genel olarak araştırma hipotezleri, uygulanan analiz yöntemleri ve örnekleme alınan kişilerin meslekleri olarak belirlenmiștir.

Araștırmada veri tabanı olarak YÖK Ulusal Tez Merkezi ve PubMed kullanılmıştır. Bu veri tabanları içerisinde yapılan değerlendirmeye "son on yıl içerisinde yapılan çalışmalar" dahil edilmiştir. Ulusal tez merkezinde içerisinde "iş stresi” ve "iş doyumu/iş tatmini" kelimelerinin beraber geçtiği tezler araştırılmıştır. Elde edilen 42 yüksek lisans ve doktora tezi içerisinde öncelikle tez özetlerinin incelenmesi ve ardından araştırma yöntemi, örneklem ve hipotezlerinin uygun olup olmadığının incelenmesi sureti ile 32 tez elenmiş, toplamda
9 yüksek lisans ve 1 doktora tezi araştırmaya dahil edilmiştir.

Bir diğer veri tabanı olan PubMed üzerinde "occupational stress/job stress" ile "job satisfaction" kelimelerinin aynı anda geçtiği çalışmalar incelenmiştir. $\mathrm{Bu}$ kapsamda elde edilen çalışma sayısı 68 olarak belirlenmiştir. Çalışma özetleri ve yöntemleri araştırma kapsamına uygunluk açısından incelenmiş ve 4 makale araștırmaya dahil edilmiștir. Aynı veri tabanında "iş stresi" ve "iş doyumu/iş tatmini" kelimeleri taranmıș, ancak araştırma kapsamına dahil edilebilecek, kriterleri sağlayan bir çalışmaya rastlanmamıştır. Toplamda 14 adet çalışma bu araştırmanın örneklemini oluşturmuştur.

Çalışmaların araştırmaya dahil edilme kriterleri aşağıdaki gibidir:

1.Kriter: Araştırma kapsamında incelenen konular çeşitli değişkenler açısından sıklıkla incelense de bu iki kavramın birbirleri ile ilişkisini araştıran az sayıda yayın olmasından dolayı son on yıl içerisinde yayınlanmış bütün tezler ve makaleler araştırılmıştır.

2.Kriter: Araştırma Ulusal Tez Merkezi ve PubMed veri tabanları ile kısıtlanmıştır. Ulusal Tez Merkezinde tezler taranırken; PubMed, sağlık alanında yayın yapan çok sayıda alan indeksli dergiyi taraması nedeni ile seçilmiştir.

3.Kriter: Veri tabanlarında "İş stresi" ve "iş tatmini/iş doyumu" değişkenlerini aynı anda içeren Türkçe makaleler ile "Occupational 
stress/job stress" ve "job satisfaction" kelimelerini içeren İngilizce makaleler taranmıştır.

4.Kriter: Örneklemi sağlık çalışanlarından seçilmiş olan araştırmalar çalışmaya dahil edilmiştir.

5.Kriter: Elde edilen bilimsel çalışmaların özetleri ve araştırma yöntemleri incelenmiştir. Buna göre araştırmalardan kantitatif özellik gösterenler araştırmaya dahil edilmiştir.

6.Kriter: Elde edilen araştırmaların hipotezleri ve/veya çalışma soruları incelenmiştir. Buna göre iş stresinin iş doyumu/tatmini üzerindeki etkisini incelemiş olan çalışmalar araştırmaya dahil edilmiştir.

7.Kriter: Elde edilen araştırmalardan "genel iş tatmini/doyumu" ve "iş stresi” puanları ile korelasyon analizi yapan çalışmalar seçilmiştir. Puanları gruplandırarak bağımsız gruplar arasındaki farkların incelendiği araştırmalar kapsam dıșı bırakılmıștır.

$\mathrm{Bu}$ kapsamda araştırmaya dahil edilen ve edilmeyen çalışmaların profili aşağıdaki gibidir (Tablo 1).

\section{BULGULAR}

Dahil edilme kriterlerini sağlayan toplam 9 yüksek lisans ve 1 doktora tezi ile 4 makale araştırmaya dahil edilmiştir. Araştırmaya dahil edilen çalışmalara ilişkin tablo aşağıdaki gibidir (Tablo 2).
Araştırmaya dahil edilen çalışmaların verileri, Comprehensive Meta Analysis (CMA) programına girilmiş ve analiz edilmiştir.

Çalışmada öncelikle sabit etkiler veya rastgele etkiler modellerinden hangisinin kullanılacağının tespiti için heterojenlik testi gerçekleştirilmiştir. Yapılan analiz sonucuna göre analiz yöntemi olarak rastgele etkiler modelinin kullanılması gerektiği tespit edilmiştir $(p<0.05) .^{21}$ Analize ilişkin tablo aşağıdaki gibidir (Tablo 3).

$\mathrm{X}^{2}$ Tablosunda yer alan \%95 güven aralığında 13 serbestlik derecesine karşılık gelen değer 22,362 olarak tespit edilmiştir. Q değeri, $X^{2}$ tablosundan elde edilen kritik değeri aşmaktadır. Dolayısı ile bu analiz de meta analizde rastgele etkiler modelinin kullanılması gerektiğini göstermektedir.

Diğer taraftan, meta analize tabi tutulan çalışmaların örneklemlerinin farklı kurumlar, bölgeler ve farklı tip sağlık çalışanlarından elde edilmesinden dolayı teorik olarak da rastgele etkiler modelinin kullanılması gerekmektedir. Yapılan homojenlik testinin ardından, araştırmaya dahil edilen çalışmalar açısından yayın yanlılığının olup olmadığının tespit edilebilmesi için araştırmalara ait "Funnel Plot" grafiği incelenmiştir (Şekil 1).

Araştırmaya dahil edilen çalışmalarda yayın yanlılığının olup olmadığını gösteren grafiğe göre (Funnel Plot) araştırmalarda yayın yanlılığının olmadığını söylemek mümkündür. 
Zira yayın yanlılığı olduğunu gösteren bir grafikte çalışmaların büyük çoğunluğu bir tarafta toplanmakta veya grafiğin alt kısımlarına doğru yoğunlaşmaktadır.

Çalışma kapsamında homojenlik ve yayın yanlılı̆g incelemelerinin ardından, rastgele etkiler modeline göre etki büyüklüğü hesaplanmıştır. Elde edilen meta analiz diyagramı (orman grafiği-forest plot) aşağıdaki gibidir (Şekil 2).

Gerçekleştirilen analiz sonucunda elde edilen meta analiz diyagramına göre, sağlik çalışanlarında iș stresinin iş tatminini olumsuz yönde ve orta düzeyde etkilediği söylenebilmektedir. Korelasyon analizlerinin meta analize tabi tutulması ile elde edilen sonuç $-0,275$ olarak tespit edilmiştir. Tek tek çalışmalar incelendiğinde bir adet çalışma dışında 0,00 noktasını kesen hiçbir çalışma olmadığı görülmektedir. P değerlerine bakıldığında da durum anlaşılmaktadır. Buna göre "Ertürk, 2011" isimli çalışma dişında anlamlılığı olumsuz etkileyen bir çalışma yoktur.

\section{TARTIŞMA VE SONUÇ}

İş stresi ile iş tatmini literatürü incelendiğinde hem Türkiye hem de dünya literatüründe bu alanlar ile ilgili çok sayıda araştırma yapıldığ 1 görülecektir. Araştırmalar genellikle çeşitli değişkenlerin iş stresine ve iş doyumuna etkisinin incelenmesi amaci ile gerçekleştirilmiştir. Ancak iş stresinin iş doyumuna etkisini doğrudan inceleyen araştırma sayısı kısıtlıdır. Kısıtlı da olsa bu araştırmaların çoğunda çalışanların stres düzeylerinin iș doyumlarını olumsuz etkilediği sonucuna varılmıștır. Aynı șekilde bu araştırmaları sağlık çalışanları örnekleminde gerçekleştiren çalışmalar da son derece azdır. $\mathrm{Bu}$ araştırmaların çoğunda da iş stresinin iş doyumu üzerinde negatif bir etkisi olduğu sonucuna ulaşılmıştır. Farklı örneklemler ile yapılan araștırmalarda bu etkinin gücü ile ilgili sonuçlar da değişkenlik göstermektedir. $\mathrm{Bu}$ kapsamda, farklı örneklemler ile gerçekleştirilmiş farklı çalışmaların sonuçlarının bir araya getirilerek analiz edildiği bu çalışmada iş stresinin iş doyumu üzerindeki etki büyüklüğü $-0,275$ olarak saptanmıştır. Dolayısı ile iş stresinin iș doyumunu orta düzeyde olumsuz yönde etkilediği söylenebilir. $\mathrm{Bu}$ durum özellikle yoğun stres altında çalışan sağlık çalışanları açısından önem kazanmaktadır. Zira sağlık çalıșanları yüksek stres altında ve hataların bedellerinin çok yüksek olduğu bir iş ortamında faaliyet göstermektedirler. ${ }^{22}$ İş doyumu yüksek bir çalışanın işe bağlılığı, motivasyonu ve performansı da yüksek düzeylerde olmakta, dolayısı ile hastaların memnuniyetleri de artmaktadır. Aynı zamanda hata oranlarında azalmalar sağlanabilmektedir. İşine motive olmuş bir çalışanın takım arkadaşlarını motive etmesi de daha kolay olmakta ve ortaya yüksek 
performanslı ekipler çıkmaktadır. ${ }^{23} \mathrm{Bu}$ nedenle sağlık çalışanlarına yönelik olarak stres yaratan unsurların ortadan kaldırılması ve çalışanlara stres ile başa çıkma yöntemlerinin aktarılması çok önemlidir.

İş tatmininin düşük olduğu durumlarda iş doyumsuzluğu söz konusu olmaktadır. İş doyumsuzluğunun olduğu durumların iş görenin iş ile ilişkisini doğrudan etkilediği açıktır. İş doyumsuzluğu iş görenlerin performanslarını düşürmek ile kalmamakta; aynı zamanda işten ayrılma niyetlerini artırmakta, psikolojik sağlıklarını bozmakta ve bazı fiziksel problemleri de beraberinde getirmektedir. Bununla beraber işten ayrılmasalar dahi çalışanların işe devamsızlık oranlarını artırarak üretim süreçlerinde aksamalara sebep olmaktadır. $\mathrm{Bu}$ durum sağlık gibi devamlılığın ve takibin önemli olduğu sektörlerde müşteri memnuniyetinde ciddi düşüşlere sebep olabilmektedir. İş doyumu düşük olan çalışanların hata yapma olasılıkları da artmakta, sağlık gibi hata kabul etmeyen alanlarda hizmet kalitesinin olumsuz etkilenmesi müşteri/hasta pozisyonunda olan bireylere yansımakta ve ilk aşamalarda sadece bireysel memnuniyetsizlikler ortaya çıksa da ilerleyen dönemlerde kurum imajını büyük ölçüde zedelemektedir. İş doyumsuzluğun diğer bir sonucu da örgütsel bağların zayıflayarak kopma noktasına gelmesidir. Örgütsel bağların ve iletişimin zayıflaması hem aynı düzey çalışanlar arasında yatay, hem de ast-üst arasında dikey çatışmaların yaşanmasına yol açabilmektedir. Böyle bir durumda örgütler kırılgan bir yapıya dönüşebilir ve en ufak problemlerde dahi büyük krizlerin içine sürüklenebilirler.

Örgütlerde iş doyumunun yüksek olması, yöneticilerin değerlendirilmesi açısından önemli bir kriter olarak görülebilmektedir. Bu anlamda örgüt çalışanlarının doyum düzeyinin yüksek olmas1, örgütün iyi yönetildiği düşüncesini de doğurmaktadır. Dolayısı ile sağlık yöneticileri açısından sağlık çalışanlarının yüksek bir doyum düzeyine ulaşmaları ve yüksek iş doyumunun sürdürülebilirliğinin sağlanması önemli bir başarı faktörü olarak ifade edilebilir. Ülkemizde sağlık alanında son zamanlarda gündeme gelmiş olan ve Toyota ile özdeşleşmiş olan yalın üretim de esasında yüksek performans ve sıfır hata ile üretim yapılması üzerine odaklanmıştır. Yüksek performans, minimum maliyet ve yüksek verimlilik ile çalışılabilmesinin ön koşullarından bir tanesi de nitelikli çalışanlardır. Ancak çalışanların nitelikleri ne kadar yüksek olursa olsun, iş doyumsuzluğu ve stres gibi unsurlar hata oranlarını ve fireleri artırmakta, iş kazalarına ve iş güvenliği sorunlarına yol açmakta, dolayısıyla işletmeleri hem maddi hem de hukuki açıdan zor durumda bırakmaktadır. $\mathrm{Bu}$ bağlamda yalın hastanecilik konusundaki ilerlemenin de çalışanların yüksek iş doyumuna sahip olması ile yakından ilişkili olduğu iddia edilebilmektedir. Özellikle sağlık sektöründe son zamanlarda gündeme gelen malpraktis 
vakaları ve açılan davalar konunun öneminin daha iyi anlaşılmasına yardımcı olmaktadır. $\mathrm{Bu}$ noktada sağlık sektöründe minimum hata, hatta mümkünse sıfır hata ile çalışılması hedeflenmelidir.

Sağlık çalışanlarının yüksek bir iş doyumuna ulaşabilmeleri adına, iş ortamlarında stres yaratan faktörlerin minimum seviyeye indirilmesi, çalışanlara stres ile mücadele eğitimlerinin verilmesi gibi önlemler alınmalıdır. Böylece yüksek iş doyumuna sahip olan sağlık çalışanları, daha yüksek bir performans ile çalışabilecek ve sağllk kurumlarının verimliliklerine katkı sağlayabilecektir. Aynı zamanda, stres ile başa çıkma konusunda eğitimli ve başarılı sağlık çalışanlarının malpraktis oranlarının düşmesi ile sağlık kurumlarının özellikle hukuki anlamda problemlerden kaçınması olanaklı olacaktır. Benzer şekilde iş sağlığı ve güvenliği sorunlarının yaşanmaması adına, sağlık yöneticileri sağlık çalışanlarının stres düzeylerini minimize ederek iş doyumlarını artıracak önlemler almalıdır.

\section{KAYNAKLAR}

(*) ile işaretli olanlar meta analizde kullanılan çalışmalardır.

1. Cooper CL, Dewe PJ, O'Driscoll MP. Organizational Stress: A Review and Critique of Theory, Research, and Applications. California: Sage; 2001.
2. Harigopal K. Organizational Stress: A Study of Role Conflict. Universities Press; 1995.

3. Şimşek Ş, Çelik A, Akgemci T. Davranış Bilimlerine Giriş ve Örgütsel Davranış, 9. Bask1, Ankara: Eğitim Kitabevi; 2015.

4. Eren E. Örgütsel Davranış ve Yönetim Psikolojisi. 11. Bask1, İstanbul: Beta Yayınc1lık; 2008.

5. Soysal A. İş yaşamında stres. Çimento İşveren Dergisi. 2009; 3(23): 17-40.

6. Balcı A. Öğretim Elemanlarının İş Stresi, Kuram ve Uygulamalar. Ankara: Nobel Yayınevi; 2000.

7. Erdoğan T, Ünsar AS, Süt N. Stresin çalışanlar üzerindeki etkileri: bir araştırma. Süleyman Demirel Üniversitesi İktisadi ve İdari Bilimler Fakültesi Dergisi. 2009; 14(2): 447-461.

8. Balcı A. Çalışanlarda stres kaynakları, stresle başa çıkma yöntemleri ve sağlık sektörü. Yüksek Lisans Tezi. Beykent Üniversitesi, Sosyal Bilimler Enstitüsü; 2014.

9. Ergun G. Sağlık işletmelerinde örgütsel stresin işgücü performansıyla etkileşiminin incelenmesi. Yüksek Lisans Tezi. Dokuz Eylül Üniversitesi, Sosyal Bilimler Enstitüsü; 2008.

10. Hubbard JR (Ed.). Handbook of Stress Medicine: An Organ System Approach. New York: CRC Press; 1997.

11. Wilson B. Understanding Autoimmune Disease and Stress-Related Illness, NC: Lulu Publishing; 2009. 
12. Sabuncuoğlu Z, Tüz M. Örgütsel Psikoloji. 1. Bask1, Bursa: Ezgi Kitabevi; 1995.

13. Okutan M, Tengilimoğlu D. İş ortamında stres ve stresle başa çıkma yöntemleri: bir alan uygulaması. İktisadi ve İdari Bilimler Fakültesi Dergisi. 2002; 4(3): 15-42.

14. Eren Gümüştekin G, Öztemiz AB. Örgütlerde stresin verimlilik ve performansla etkileşimi. Çukurova Üniversitesi Sosyal Bilimler Enstitüsü Dergisi. 2005; 14(1): 271288.

15. Eren E. Yönetim Psikolojisi. 4. Bask1, İstanbul: Beta Yayıncılık; 1993.

16. Robbins SP, Judge TA. Organizational Behavior. Çeviri: İnci Erdem, Örgütsel Davranış. 14. Baskı, İstanbul: Nobel Yayınc1lık; 2015.

17. Bingöl D. Personel Yönetimi. 2. Bask1, İstanbul: Beta Yayıncılık; 1996.

18. İşcan ÖF, Sayın U. Örgütsel adalet, iş tatmini ve örgütsel güven arasındaki ilişki. Atatürk Üniversitesi İktisadi ve İdari Bilimler Dergisi. 2010; 24(4): 195-216.

19. Spector PE. Job Satisfaction: Application, Assessment, Causes, and Consequences. California: Sage Publication; 1997.

20. Kaptangil K. İşletmelerde insan kaynakları eğitiminin çalışanların performansları üzerine olan etkileri. Çankırı Karatekin Üniversitesi İktisadi ve İdari Bilimler Fakültesi Dergisi. 2012: 2(2); 25-44.

21. Yalçın İ. İyi Oluş ve sosyal destek arasındaki ilişkiler: Türkiye'de yapılmış çalışmaların meta analizi. Türk Psikiyatri Dergisi. 2015; 26(1): 21-32.

22. Kavuncubaşı Ş. Hastane ve Sağlık Kurumları Yönetimi, Ankara: Siyasal Kitabevi; 2000.

23. Hoș C, Oksay A. Hemșirelerde örgütsel bağlılık ile iş tatmini ilişkisi. Süleyman Demirel Üniversitesi İktisadi ve İdari Bilimler Fakültesi Dergisi. 2015; 20(4): 1-24.

*Arız T. İş tatmini ile stres düzeyleri ilişkisi: Ankara Gölbaşı Hasvak ve Kalecik Devlet Hastaneleri örneği. Yüksek Lisans Tezi, Ankara Üniversitesi, Sağlık Bilimleri Enstitüsü, Ankara; 2010.

*Chao MC, Jou RC, Liao CC, Kuo CW. Workplace stress, job satisfaction, job performance, and turnover intention of health care workers in rural Taiwan. Asia Pacific Journal of Public Health. 2015; 27(2), 18271836.

*Ertürk S. Kuruma aidiyet bağlamında adanmışlık algısı ile kişilik, iş doyumu ve stres ilişkisi. Doktora Tezi, Kara Harp Okulu, Savunma Bilimleri Enstitüsü, Ankara; 2011.

*Göçeri F. Sorumlu hemşirelerin iş stresinin iş doyumu üzerine etkisi. Yüksek Lisans Tezi, Haliç Üniversitesi, Sağlık Bilimleri Enstitüsü, İstanbul; 2014.

* Kara T. Hemşirelerde stresin iş tatmini ve işten ayrılmaya etkisinin çalışma saatleri açısından değerlendirilmesi. Yüksek Lisans Tezi, Beykent Üniversitesi, Sosyal Bilimler Enstitüsü, İstanbul; 2010. 
*Kurumahmut D. İstanbul' daki özel diyaliz merkezlerinde çalışan hemodiyaliz hemşirelerinin stres düzeyleri ve stres düzeylerinin iş doyumuna etkisi. Yüksek Lisans Tezi, Haliç Üniversitesi, Sağlık Bilimleri Enstitüsü, İstanbul; 2010.

*Melnyk BM, Hrabe DP, Szalacha LA. Relationships among work stress, job satisfaction, mental health, and healthy lifestyle behaviors in new graduate nurses attending the nurse athlete program: a call to action for nursing leaders. Nursing administration quarterly. 2013; 37(4), 278285.

*Narin Y. İstanbul ilinde bir eğitim araştırma hastanesinde çalışan hemşireleri rol çatışması, iş doyumu ve stres düzeylerinin belirlenmesi. Yüksek Lisans Tezi, Haliç Üniversitesi, Sağlık Bilimleri Enstitüsü, İstanbul; 2010.

*O'Donnell P, Farrar A, BrintzenhofeSzoc K et al. Predictors of ethical stress, moral action and job satisfaction in health care social workers. Social Work in Health Care. 2008; 46(3), 29-51.

*Şahin, Z. Bir devlet hastanesinde çalışan hemşireler ile bir vakıf üniversitesi hastanesinde çalışan hemşirelerin iş stres ve iş doyumu düzeylerinin incelenmesi. Yüksek Lisans Tezi, Maltepe Üniversitesi, Sosyal Bilimler Enstitüsü, İstanbul; 2011.

*Tanşu M. Örgütsel stres kaynakları ve iş tatmini arasındaki ilişkinin incelenmesi ve sağlık sektöründe bir uygulama. Yüksek Lisans Tezi, Yıldız Teknik Üniversitesi, Sosyal Bilimler Enstitüsü, İstanbul; 2009.

*Tremolada M, Schiavo S, Tison T et al. Stress, burnout, and job satisfaction in 470 health professionals in 98 apheresis units in Italy: A SIdEM collaborative study. Journal of Clinical Apheresis. 2015; 30(5), 297-304.

*Vural Z. Sağlık çalışanlarında örgütsel stresin iş tatmini ile ilişkisi (Antalya Atatürk Devlet Hastanesi hemşireleri örneği). Yüksek Lisans Tezi, Beykent Üniversitesi, Sosyal Bilimler Enstitüsü, İstanbul; 2014.

*Yalnız H. Ebelerde iş stresinin iş doyumuna etkisi. Yüksek Lisans Tezi, Ege Üniversitesi, Sağlık Bilimleri Enstitüsü, İzmir; 2010. 
Tablo 1. Veri tabanlarından elde edilen çalışmaların profili

\begin{tabular}{cccc}
\hline Çalışma Türü & Dâhil Edilen & Dâhil Edilmeyen & Toplam \\
\hline Yüksek Lisans ve Doktora Tezi & 10 & 32 & 42 \\
Makale & 4 & 64 & 68 \\
TOPLAM & 14 & 96 & 110 \\
\hline
\end{tabular}

Tablo 2. Araştırmaya dahil edilen çalışmalar

\begin{tabular}{|c|c|c|c|c|}
\hline Çalışma & Çalışmanın Tam İsmi & Türü & $\begin{array}{l}\text { Örneklem } \\
\text { Büyüklüğü }\end{array}$ & $\begin{array}{c}\text { Temel } \\
\text { Bulgular (r) }\end{array}$ \\
\hline Ar1z, 2010 & $\begin{array}{l}\text { İş tatmini ile stres düzeyleri ilişkisi: } \\
\text { Ankara Gölbaşı Hasvak ve Kalecik Devlet } \\
\text { Hastaneleri örneği }\end{array}$ & $\begin{array}{l}\text { Yüksek } \\
\text { Lisans Tezi }\end{array}$ & 276 & $-0,350$ \\
\hline Chao, 2015 & $\begin{array}{l}\text { Workplace stress, job satisfaction, job } \\
\text { performance, and turnover intention of } \\
\text { health care workers in rural Taiwan }\end{array}$ & Makale & 344 & $-0,530$ \\
\hline Ertürk, 2011 & $\begin{array}{l}\text { Kuruma aidiyet bağlamında adanmışlık } \\
\text { algısı ile kişilik, iş doyumu ve stres ilişkisi }\end{array}$ & $\begin{array}{l}\text { Doktora } \\
\text { Tezi }\end{array}$ & 200 & $-0,115$ \\
\hline Göçeri, 2014 & $\begin{array}{l}\text { Sorumlu hemşirelerin iş stresinin iş } \\
\text { doyumu üzerine etkisi }\end{array}$ & $\begin{array}{l}\text { Yüksek } \\
\text { Lisans Tezi }\end{array}$ & 165 & $-0,395$ \\
\hline Kara, 2010 & $\begin{array}{l}\text { Hemşirelerde stresin iş tatmini ve işten } \\
\text { ayrılmaya etkisinin çalışma saatleri } \\
\text { açısından değerlendirilmesi }\end{array}$ & $\begin{array}{l}\text { Yüksek } \\
\text { Lisans Tezi }\end{array}$ & 175 & $-0,309$ \\
\hline $\begin{array}{l}\text { Kurumahmut, } \\
2010\end{array}$ & $\begin{array}{l}\text { İstanbul' daki özel diyaliz merkezlerinde } \\
\text { çalışan hemodiyaliz hemşirelerinin stres } \\
\text { düzeyleri ve stres düzeylerinin iş } \\
\text { doyumuna etkisi }\end{array}$ & $\begin{array}{l}\text { Yüksek } \\
\text { Lisans Tezi }\end{array}$ & 171 & $-0,357$ \\
\hline Melnyk, 2013 & $\begin{array}{l}\text { Relationships among work stress, job } \\
\text { satisfaction, mental health, and healthy }\end{array}$ & Makale & 61 & 0,530 \\
\hline
\end{tabular}


lifestyle behaviors in new graduate nurses attending the nurse athlete program: a call to action for nursing leaders

Narin, 2010

O’Donnel, 2008

Şahin, 2011

Tansu, 2009

Tremolada, 2015

Vural, 2014

Yaln1z, 2010

İstanbul ilinde bir eğitim çatışması, iş doyumu ve stres düzeylerinin belirlenmesi

Predictors of ethical stress, moral action

and job satisfaction in health care social workers ile bir vakıf üniversitesi hastanesinde çalışan hemşirelerin iş stres ve iş doyumu düzeylerinin incelenmesi sektöründe bir uygulama

health professionals in 98 apheresis units in Italy: A SIdEM collaborative study

Sağlık çalışanlarında örgütsel stresin iş tatmini ile ilişkisi (Antalya Atatürk Devlet Hastanesi hemşireleri örneği)

Ebelerde iş stresinin is doyumuna etkisi hastanesinde çalışan hemşireleri rol

Makale

Bir devlet hastanesinde çalışan hemşireler Yüksek 198 $-0,594$

Örgütsel stres kaynakları ve iş tatmini Yüksek arasındaki ilişkinin incelenmesi ve sağlık Lisans Tezi

Stress, burnout, and job satisfaction in 470

Makale

Yüksek

Lisans Tezi 
Tablo 3. Heterojenlik analizi

Q Değeri $\quad$ Serbestlik Derecesi $\quad$ P $\quad I^{2}$ Değeri

Şekil 1. Araştırmaya dahil edilen çalışmalara ilişkin yayın yanlılığı grafiği

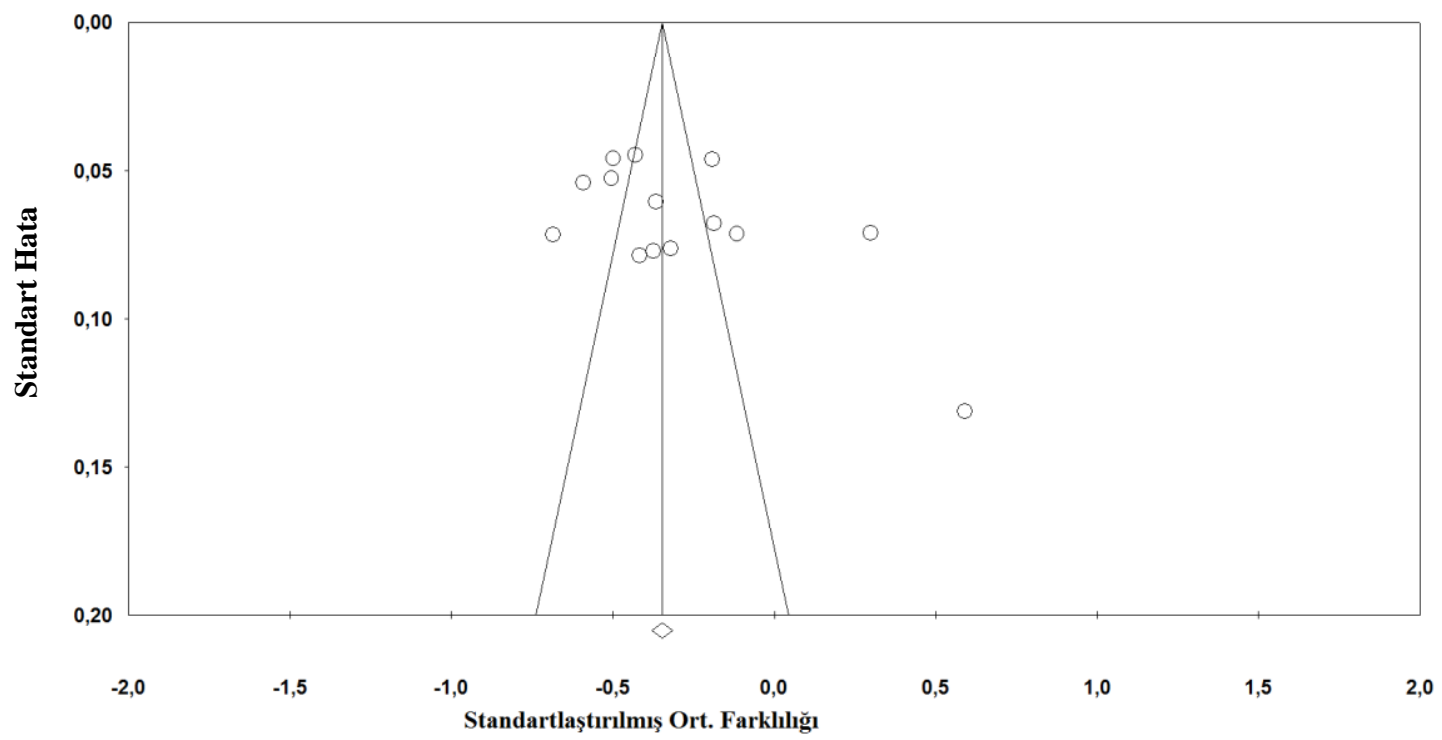


Şekil 2. Çalışmaya ilişkin meta analiz diyagramı

\begin{tabular}{|c|c|c|c|c|c|c|c|c|c|}
\hline \multirow[t]{2}{*}{ Calıșma İsmi } & \multicolumn{5}{|c|}{$\underline{\text { Her Bir Calısmava Ait İstatistikler }}$} & \multicolumn{4}{|c|}{ Korelasyon ve \%95 Güven Aralığı } \\
\hline & Korelasyon & $\begin{array}{l}\text { Alt } \\
\text { Sinir }\end{array}$ & $\begin{array}{l}\text { Üst } \\
\text { Sinır }\end{array}$ & Z Değeri & P Değeri & & & & \\
\hline Ariz, 2010 & $-0,350$ & $-0,449$ & $-0,242$ & $-6,038$ & 0,000 & & & & \\
\hline Chao, 2015 & $-0,530$ & $-0,602$ & $-0,449$ & $-10,898$ & 0,000 & & & & \\
\hline Erturk, 2011 & $-0,115$ & $-0,250$ & 0,024 & $-1,621$ & 0,105 & & & & \\
\hline Goceri, 2014 & $-0,395$ & $-0,517$ & $-0,258$ & $-5,317$ & 0,000 & & & & \\
\hline Kara, 2010 & $-0,309$ & $-0,437$ & $-0,168$ & $-4,189$ & 0,000 & & & & \\
\hline Kurumahmut, 2010 & $-0,357$ & $-0,481$ & $-0,219$ & $-4,840$ & 0,000 & & & & \\
\hline Melnyk, 2013 & 0,530 & 0,321 & 0,690 & 4,494 & 0,000 & & & & \\
\hline Narin, 2010 & $-0,184$ & $-0,309$ & $-0,053$ & $-2,742$ & 0,006 & & & & \\
\hline O'Donnel, 2008 & $-0,461$ & $-0,529$ & $-0,387$ & $-10,866$ & 0,000 & & & & \\
\hline Sahin, 2011 & $-0,594$ & $-0,677$ & $-0,496$ & $-9,549$ & 0,000 & & & & \\
\hline Tansu, 2009 & $-0,405$ & $-0,476$ & $-0,329$ & $-9,597$ & 0,000 & & & & \\
\hline Tremolada, 2015 & $-0,190$ & $-0,276$ & $-0,101$ & $-4,156$ & 0,000 & & & & \\
\hline Vural, 2014 & 0,290 & 0,158 & 0,412 & 4,201 & 0,000 & & & - & \\
\hline \multirow[t]{4}{*}{ Yalniz, 2010} & $-0,465$ & $-0,542$ & $-0,381$ & $-9,583$ & 0,000 & & & & \\
\hline & $-0,275$ & $-0,395$ & $-0,145$ & $-4,076$ & 0,000 & & & & \\
\hline & & & & & & $-1,00$ & $-0,50$ & 0,50 & 1,00 \\
\hline & & & & & & & Negatif & Pozitif & \\
\hline
\end{tabular}

Meta Analiz 